\title{
Neuroendocrine cell hyperplasia of infancy
}

INSERM

\section{Source}

INSERM. (1999). Orphanet: an online rare disease and orphan drug data base.

Neuroendocrine cell hyperplasia of infancy. ORPHA:217560

Neuroendocrine cell hyperplasia of infancy $(\mathrm{NCHI})$ is a non-lethal pediatric form of interstitial lung disease (ILD, see this term) characterized by tachypnea without respiratory failure. 